\title{
Na východ od Česka alebo ako porovnávat' náboženstvo v Česku a na Slovensku*
}

\author{
Zdeněk R. Nešpor: Česká a slovenská religiozita \\ po rozpadu společného státu. Náboženství Dioskúrů \\ Praha, Nakladatelství Karolinum 2020, 198 s.
}

\begin{abstract}
Až po vyše štvrt'storočí od rozpadu Československa a vzniku dvoch samostatných republík vznikla prvá systematickejšie zameraná monografia zaoberajúca sa situáciou v oblasti religiozity a vztáahov štátu a cirkví v oboch nástupníckych štátoch. Oceneniahodným na knihe je tiež to, že sa nesústreduje len na obdobie po rozpade spoločného štátu, ale pomerne vel'ký priestor venuje naznačeniu hlbších historických súvislostí formujúcich podobu súčasných rozdielov, a to nielen na úrovni osobnej religiozity $\mathrm{v}$ oboch krajinách, ale aj odlišného riešenia inštitucionálnych vztáahov štátu a cirkví. Na tieto dve hlavné dimenzie knihy - teda na analýzu religiozity a analýzu inštitucionálnych vztáahov štátov a cirkví - treba upozornit' hned' v úvode. Názov totiž môže mylne vytvárat' očakávania, že kniha sa zaoberá len komparáciou úrovne alebo podôb religiozity $\mathrm{v}$ oboch spoločnostiach, obzvlášt ak táto čast’ knihy je len jej menej rozsiahlym pilierom. Aj sám autor hned' v predhovore spomína dva hlavné piliere knihy, ked' uvádza, že jej primárnym záujmom je "sledovanie a komparácia vývoja náboženských inštitúcií a religiozity v oboch krajinách po rozpade federácie“ [s. 8]. Konštatovaním o dvojakosti „primárneho ciel'a“ však autor zároveň naznačuje, že práca bude obsahovat’ aj d’alšie ciele.
\end{abstract}

Širší tematický záber knihe dáva knihe výnimočné postavenie v odbornej spisbe publikovanej na túto tému v Česku a na Slovensku. V oboch krajinách dlhodobo absentuje práve takáto komparatívna štúdia dvoch spoločností, ktoré boli takmer sedem desatročí súčastou jedného štátneho útvaru so spoločným symbolickým a právnym rámcom a predtým boli súčastou spoločnej, hoci od druhej polovice 19. storočia duálnej rakúsko-uhorskej monarchie. No treba hned' na úvod uviest̆, že rozšírenie tematického záberu knihy vedie k nedokončenosti argumentácie každej z týchto analytických úrovní. Okrem toho ani napriek deklarovanej „proporčnosti“ vybraných prejavov religiozity a jej prejavov vo verejnom priestore $\mathrm{v}$ oboch spoločnostiach [s. 9] sa autorovi nepodarilo túto ambíciu naplnit'. Miera detailnosti a interpretačnej dôslednosti je pri analýze oboch spoločností na kvalitatívne a kvantitatívne inej úrovni. Ak k tomu prirátame autorovu ambíciu zhodnotit úroveň bádania v sociológii náboženstva a v religionistike

\footnotetext{
* Text vznikol v rámci práce na grantovej úlohe GAČR 19-08512S „Proměny církevních morálních ekonomií v ČR a SR v kontextu restitucí a odluky státu a církve“.
}

(C) Sociologický ústav AV ČR, v. v. i., 2021

(C) Autor, 2021 
v oboch krajinách, nedá sa vyhnút konštatovaniu, že autor nedokázal udržat' jednotnú a konzistentnú líniu smerovania výkladu svojej knihy a tým aj všetky ambície, ktoré v nej deklaruje. Práve ambicióznosté názvu a úvodných cielov môžu vyvolat' vel'ké očakávania, ktoré po dočítaní môžu vyvolat' pocity sklamania.

\section{Nielen religiozita}

Kniha má okrem predhovoru a prílohy osem častí, ktoré naznačujú autorovu snahu o čo najväčšiu komplexnost' uchopenia dvoj- (alebo až troj-)témy. V prvej časti autor popisuje česko-slovenskú religiozitu ako výskumnú tému. Podobne ako aj názov knihy, táto čast' vytvára dojem, akoby sa chcela venovat' fenoménu česko-slovenskej religiozity, akoby niečo také ako česko-slovenská religiozita existovalo. Čitatel' však bude sklamaný, a to z viacerých dôvodov. V tejto kapitole autor nepracuje s nejakou jednou religiozitou, ktorú by vnútorne diferencoval, ale skôr približuje niektoré špecifiká a odlišnosti v religiozite v Česku a na Slovensku po roku 1990, teda porovnáva religiózne situácie v dvoch kontextoch. Robí to na základe pomerne deskriptívneho opísania podielu subjektívne prihlásených k cirkvi (čo autor v názve tabul'ky 1 na s. 14 popisuje akoby šlo o členov cirkvi) vo vybraných európskych krajinách, ako ukazujú výsledky Európskeho výskumu hodnôt (EVS) v zatial' poslednej vlne v roku 2017. Nejde dokonca ani o komparáciu vel'kostne podobných alebo geograficky blízkych krajín, ale zoznam obsahuje vel'mi rôzne skupiny krajín bez toho, aby ich autor vôbec rozlíšil do skupín podla dominantnej tradície. Nábožensky rôznorodé krajiny sú pritom prezentované ako príklad „škály“ krajín podla miery religiozity. No tabul'ka fakticky uvádza len podiel prihlásených $\mathrm{k}$ nejakej náboženskej skupine alebo cirkvi v rôznych krajinách a nič iné.

Medzinárodná kontextualizácia by v prípade jednoznačného usúvstažnenia témy $\mathrm{k}$ situácii v Česku a na Slovensku nemusela byt’ problémom, no autor vôbec neuvádza, a to ani $\mathrm{v}$ iných častiach knihy, prečo práve $\mathrm{v}$ istých situáciách robí širšie medzinárodné porovnávania a $\mathrm{v}$ iných zasa nie. No už táto úvodná čast́ naznačuje viaceré problémy knihy - nesystematickú, či skôr epizodickú prácu s dátami, epizodické spájanie fenoménov s nejakou teoretickou perspektívou, nešpecifikovanú metodológiu a nedostatočnú hĺbku spracovania empirických dát. $\mathrm{V}$ úvodne časti pracuje s výsledkami EVS, no nikde inde sa $\mathrm{k}$ nim nevracia. Neskôr pracuje s výsledkami PEW Research Centra alebo výskumného programu ISSP, no len vo forme ilustrácií, bez hlbšieho vysvetlenia, ako vlastne možno religiozitu definovat'. Hoci kniha nesie názov odkazujúci na religiozitu, autor pracuje s týmto termínom vel'mi vol'ne a na mnohých miestach ju stotožňuje s členstvom $\mathrm{v}$ cirkvi, inde zamieňa subjektívne prihlásenie sa k náboženstvu za synonymum členstva v cirkvi a tým aj za synonymum religiozity. No pravdou je, že samotná religiozita nie je v rámci knihy ústredným problémom. Kniha sa totiž uberá množstvom rôznych smerov, čo je vidiet' hned' v úvode, kde autor nepochopitel'ne ukončuje zdôvodnenie napísania publikácie o religiozite v Česku a na Slovensku 
pasážami o medzinárodných problémoch v náboženskom živote, o strete civilizácií P. Huntingtona alebo o náboženskom nacionalizme, či terorizme, hoci kniha sa týmto témam už dálej nevenuje.

Trocha nepatrične pôsobí aj záver prvej kapitoly. Tu pri rozbore komparatívnych výskumov náboženstva $v$ českej a slovenskej spoločnosti autor neupresňuje, že ním uvedení českí autori sa venovali analýze českej religiozity a nie česko-slovenskej komparácii. Práve nerozlišovanie, kedy ide o popis situácie v Česku a kedy je text o Slovensku sa však v knihe objavuje viackrát, čo je len na škodu jasnosti a prehl'adnosti argumentácie. Na druhej strane si nevšíma viaceré štúdie českých a slovenských autorov obsahujúce v rámci širších medzinárodných komparácií z kvantitatívnych výskumov aj komparácie českej a slovenskej religiozity [napríklad Bunčák 2001; Tížik 2012; Váně, Stípková 2013] či vol'ne prístupnú komparáciu českej a slovenskej spoločnosti, obsahujúcu aj podrobnú komparáciu religiozity v oboch štátoch [Kusá, Tížik 2009].

\section{Asymetria komparácie}

Prvá, tematicky rôznorodá kapitola však obsahuje napríklad podkapitolu o akademickom (religionistickom) výskume náboženstva v oboch krajinách, kde sa autor pokúša naznačit' personálne a inštitucionálne zázemie tohto smeru bádania. Napriek tomu, že sa tomuto už systematickejšie venovali iní, v knihe nespomenutí autori [Bubík 2015; Václavík 2015], nejde v podstate o analýzu, ale len letmý dotyk reálnej situácie. Podobne ako v pasážach o výsledkoch kvantitatívnych výskumov aj tu vidiet' nevyváženost' pri zhodnocovaní v prospech podrobnejšej analýzy českého akademického prostredia. To by ani nemusel byt problém, ak by došlo k adekvátnej interpretácii výsledkov porovnávania. Pri takomto porovnaní by nebolo hodnotenie úrovne českého skúmania náboženstva vnímané tak negatívne a hodnotené ako nedostatočné. Pri prehlade pracovísk a autorov (hoci neúplnom) v Česku a na Slovensku je totiž neprehliadnutelné, že v spoločnosti (českej), kde sa len menšina obyvatel'stva hlási k nejakému náboženstvu a ešte menšia čast' ho aj praktizuje, existuje taká rozvetvená a početná sieť akademikov, inštitúcií i časopisov, ktoré náboženstvo akademicky skúmajú. V tom sa situácia výrazne odlišuje od Slovenska, kde napriek vysokej miere deklarovanej religiozity je akademickému a obzvlášt sociologickému výskumu venovaná vel'mi malá pozornost' a personálne je slovenské akademické prostredie v porovnaní $\mathrm{s}$ českým $\mathrm{v}$ podstate početne zanedbatel'né. Je škoda, že pri malom počte špecializovaných pracovníkov na Slovensku skúmajúcich náboženstvo vypadli aj sociologizujúci autori z iných ako explicitne sociologických alebo religionistických pracovísk. Ak sú v českom prostredí spomínané aj štúdie z oblasti geografie, na Slovensku sú nezanedbatel'né práce geografa a demografa Juraja Maja [Majo 2011; Majo 2013; Majo, Šprocha 2016] alebo Reného Matloviča [Matlovič 2001]. Pritom práve komparácia dvoch spoločností (a teda aj akademických prostredí) dávala autorovi možnost' pri hodnoteniach zvažovat' aj kritérium, v akom stave sa 
obe akademické prostredia nachádzajú (prípadne aj v kontexte porovnatel'ných európskych krajín) a podla toho aj hodnotit úroveň či rôznorodost’ výskumu.

Táto úvodná čast' knihy je zaujímavá aj z toho hladiska, ako sa autor systematicky (a pokračuje $\mathrm{v}$ takom duchu v prvých dvoch tretinách celej knihy) definuje za religionistu, píše o religionistike, religionistickom bádaní a podobne, aby celú knihu nakoniec v závere označil ako sociologickú. Samozrejme, ide o detail, no u pozorného čitatel'a môže vzniknút otázka, či autor považuje tieto dve disciplíny za identické, alebo či medzi nimi vidí nejaké rozdiely. Úvodná kapitola však obsahuje ešte jednu čast́ zdôvodňujúcu význam knihy. Jej súčastou je okrem iného prvok, ktorý sa prejavuje v celej knihe - naznačovanie odlišností Česka a Slovenska, akoby to boli dva extrémne odlišné príklady. To však autora vedie často $\mathrm{k}$ prehliadaniu podobností medzi oboma krajinami. Táto dichotomickost' sa ukazuje napríklad v tom, že o českej spoločnosti hovorí ako o proticirkevne naladenej, pričom slovenskú zároveň charakterizuje ako spoločnost', kde sa uplatňuje „súručenstvo vzájomnej podpory medzi politikmi a predstavitelmi niektorých vybraných cirkvï [s. 27]. Akoby aj v Česku neboli viditel'né politické spojenectvá a väzby medzi najvyššími predstavitel'mi politického a cirkevného života (prezident Zeman a arcibiskup Duka a podobne). Takouto dichotomizáciou kniha prispieva čiastočne k exotizácii Slovenska pre českého čitatel'a a Česka pre čitatela slovenského, prípadne $\mathrm{k}$ utvrdeniu v najsilnejších stereotypoch voči každej z krajín.

Druhá časț knihy nazvaná Spoločné východiskové body má akoby metodologický charakter. Obsahovo sa však venuje najskôr európskej religiozite, od ktorej autor prechádza k spoločnej histórii oboch krajín ešte v Habsburskej monarchii a neskôr v spoločnom Československu. Tu autor naznačuje historické korene rozdielov medzi českou a slovenskou spoločnostou, v ktorých sa v 19. storočí formovalo národné hnutie s odlišnými väzbami na náboženstvo. Jednou z pripomienok $\mathrm{k}$ tejto časti môže byţ autorovo precenenie úlohy evanjelických elít $\mathrm{v}$ národnom hnutí na Slovensku v období národného obrodenia. Je pravdou, že evanjelické elity boli v národnom hnutí početnejšie a aktívnejšie, no základom a charakteristickou črtou úspechu národného hnutia bolo ich programové spojenie s katolíckymi národnými buditel'mi a vytvorenie istého druhu konfesionálneho dualizmu, ktorý bol jadrom národného hnutia v podstate až do vypuknutia prvej svetovej vojny.

Nezohladnenie rôznych špecifík, $\mathrm{v}$ istých prípadoch zásadných, sa pri porovnávaní náboženskej situácie v českej a slovenskej časti monarchie javí ako výrazná slabina. Deklarovaná okrajovost́ evanjelikov v oboch častiach monarchie [s. 34] je len zdanlivá, lebo zatial' čo v českej časti monarchie v tom čase (ale aj neskôr) sa táto menšina koncentrovala v juhovýchodnej časti Sliezska a na Tešínsku, na Slovensku boli evanjelici teritoriálne prítomní na väčšine územia a stali sa dôležitou kultúrnou a národotvornou entitou aj vo vtedajších prosperujúcich mestách. Tvorili síce menšinu, ale ich podiel v rámci slovenskej populácie bol [Majo 2011; Majo 2013] v porovnaní s českou častou monarchie vyšší a ich vplyv na národné a politické hnutie Slovákov na prelome 19. a 20. storočia silnejší. V rámci Uhorska ako celku evanjelici (formálne spájajúci cirkvi luteránskeho a kalvínske- 
ho vyznania) predstavovali takmer polovicu obyvatel'stva. Ich spoločenský vplyv bol o to výraznejší, že protestantizmus ako jeden z činitel'ov vymedzovania sa uhorských elít voči Habsburgovcom sa stal súčastou identity Uhorského královstva. V tomto zmysle bol význam jednotlivých častí evanjelickej konfesie silnejší ako jej reálna početnost', a to aj v oblastiach s dominanciou katolíckych veriacich, čoho príkladom bolo aj Horné Uhorsko, teda dnešné Slovensko, kde sa koncentrovala luteránska čast' uhorského evanjelictva.

No zároveň treba aj oponovat' autorovmu mechanickému spojeniu evanjelických vyznaní a modernizačných tendencií, ked’že v prípade slovenského evanjelictva bol už v 19. storočí prítomný aj vel'mi silný antimodernizačný a hodnotovo konzervatívny prúd sústredený okolo Svätozára Hurbana Vajanského v Martine. Celkovo bolo národné hnutie so silným zastúpením evanjelikov hodnotovo konzervatívne, a to práve $\mathrm{z}$ dôvodu vymedzovania sa voči liberálnym a modernizačným mad’arským elitám. Dalo by sa povedat', že vyhranením sa voči madarskému liberalizmu, teda istému druhu sekularizmu bolo slovenské národné hnutie, a to aj v jeho liberálnejších vetvách (hlasisti) tradicionálnejšie nielen personálnym napojením na cirkvi (angažovanost' kňazov alebo detí kňazov v prípade protestantov), no aj snahou o ludovost́ a najmä zdôrazňovaním záujmov a potrieb národa. [Klobucký 2006]. Autor spája, čo je vel'mi prínosné, náboženskú situáciu luteránov v oboch krajinách s národným hnutím. Zatial čo české luteránstvo stratilo kvôli svojej nemeckosti šancu na odozvu v českej populácii [s. 36], luteráni na Slovensku zohrávali radikálne odlišnú úlohu. Slovenskí a nemeckí luteráni sa vymedzili voči madarským kalvínom, čo podporilo spojenie luteranizmu s národným princípom medzi Slovákmi. Celkovo možno konštatovat', že už východiskové úvahy knihy naznačujú silnú asymetriu v popísaní kontextov a podmienok pre náboženský život v Česku a na Slovensku. Tento problém je prítomný v celej knihe a aj preto si zaslúži podrobnejšiu reakciu práve zo slovenskej strany.

\section{Formovanie náboženských polí}

Ako aj inde v knihe, aj v časti o prvej Československej republike autor vel'mi vol'ne narába s termínom religiozita, keď̌e $\mathrm{v}$ podstate nerieši religiozitu ako náboženské založenie jednotlivcov, ale zaoberá sa najmä vztahmi cirkví k štátu (legislatívou), prípadne cirkví medzi sebou. Je to viac o fungovaní a rekompozícii toho, čo Pierre Bourdieu [napríklad v Bourdieu 1998] označuje ako náboženské pole. Pri rozbore šírenia prestupových a výstupových hnutí v novom štáte opätł dôkladnejšie popisuje českú situáciu a v prípade Slovenska sa často uchyluje k privel'kým zjednodušeniam. Vykresluje "zdesenie“ Slovákov z českého "bezbožníctva“, využíva označenie nábožensky "tradičné" obyvatel'stvo [s. 38], čím úplne obchádza viaceré popisy slabosti vplyvu cirkvi na veriacich, ako o tom písal napríklad Ján Lajčiak [1994]. No obišiel aj hnutia pôsobiace v rámci existujúcich cirkví. Aj medzi katolíckymi kňazmi boli republikáni horliaci za odluku štátu a cirkvi (príkladom bol kňaz a politik Ferdiš Juriga), ktorí boli aj politicky vel'mi aktívni. 
To, že v slovenskom politickom živote v čase prvej ČSR postupne získal dominantný vplyv luudácky katolicizmus neznamená, že spoločnost' bola, obzvlášt́ $\mathrm{v}$ čase formovania republiky, taká tradičná, homogénna a tradične katolícka, ako to popisuje kniha. Trocha odvážne pôsobia tvrdenia popisujúce, ako sa na Slovensku chopili moci evanjelici a bezverci a tí okrem iného z pozície, že držali "z vel'kej miery" v rukách úrady, využívali situáciu v "neprospech katolíckej cirkvi" [s. 38]. Autor vôbec nešpecifikoval, čo konkrétne robili a v prospech koho teda vystupovali, pričom neberie do úvahy, že v štáte nefavorizujúcom katolícku cirkev a riadenom $z$ Prahy boli aj štátne úrady viazané politikou štátu a nie miestnymi konfesionálnymi spormi. Je v prípade, ak viacnárodný štát obmedzuje možnosti cirkví možné pripisovať zodpovednoste za riešenie politiky štátu lokálnym elitám? Len o stranu dalej autor konštatuje oslabovanie vplyvu cirkví na život ludí a korozívny efekt vtedajších podmienok na tradičné náboženské identity, no $\mathrm{v}$ prípade slovenskej spoločnosti toto neberie (a ani v dáších častiach knihy) vážne. Naznačuje tým, že náboženská neutralita štátu, náboženská pluralita a odstránenie viacerých privilégií najväčšej cirkvi mali takýto dopad len na českú spoločnost́ a na slovenskú nie?

Žial', tento druh (aj paušalizujúceho) naratívu vyvoláva zdanie, ako by bol inšpirovaný lúdáckou historiografiou, teda tou historiografiou na Slovensku, ktorá ospravedlňuje režim vojnovej Slovenskej republiky a legitimizuje jej existenciu negatívnym vykreslovaním podmienok Slovenska v prvej ČSR. Obzvlášt privel'mi vol'né narábanie s bezvercami pôsobiacimi na Slovensku v štátnej správe vyznieva v tomto duchu a tiež pôsobí nepodložene vzhladom na to, že v oboch častiach nového štátu bola absolútna väčšina obyvatel'stva stále (minimálne) formálne zviazaná s niektorou cirkvou a podiel ludí bez vyznania bol mizivý. No práve dobový ludácky naratív (spojený s najsilnejšou politickou stranou na Slovensku HSL'S) spájal bezverectvo či bezbožnost' s českým živlom na Slovensku, prípadne s komunistami. Dokonca aj úplná absencia analýzy náboženskej situácie v tzv. druhej republike a v Protektoráte Čechy a Morava spolu s vojnovou Slovenskou republikou vytvárajú paralely s naratívom nie kriticky analyzujúcim celé obdobie rokov 1918-1948, teda do nástupu komunistickej strany k moci.

Ťažko odhadnút, čo inšpirovalo autora k takémuto popisu situácie na Slovensku, no mnohé konštatovania sú nielen tendenčné, ale doslova až popierajúce historickú situáciu. Napríklad pri popise povojnového vytvorenia Demokratickej strany ju autor definuje ako „dominantne evanjelickü“ (vedením?, členstvom?) a spája ju s akýmsi druhom prebudenia a sebauvedomenia sa slovenských evanjelikov, ktorí „si uvedomili, že sú menšinou, ktorá ak má obstát pred náporom komunistov a vystríhat' sa chýb svojich medzivojnových predchodcov, musí aspoň s niektorými katolikmi spolupracovat" [s. 40]. Tento záver je historicky sporný z viacerých dôvodov. Naznačuje, akoby šlo o spor komunisticko-konfesionálny (komunisti vs. evanjelici) a akoby evanjelici neboli historicky ústretoví spolupracovat' s katolíkmi. Aj skôr naznačené príklady takejto spolupráce však ukazujú, že národná a politická angažovanost́ slovenských evanjelikov bola takmer vždy spojená so spoluprácou s katolíkmi. Už od počiatkov Štúrových snáh o kodifikáciu spisovnej slovenčiny, 
od založenia Matice slovenskej a slovenských gymnázií, cez založenie Slovenskej národnej strany, všetky tieto projekty boli založené na programovom spojenectve evanjelikov a katolíkov. Aj prvorepubliková SNS a dalšie politické pokusy boli vyjadrením programovej spolupráce časti evanjelickej inteligencie v národných otázkach s katolíkmi. Vytvorenie politického katolicizmu zhmotneného v Hlinkovej slovenskej ludovej strane (HSL'S), ktorá sa stala postupne hegemónom v medzivojnovom politickom živote na Slovensku, nebolo spôsobené neochotou časti evanjelikov spolupracovat’ s katolíkmi. Bol to problém konfesionálnej profilácie Hlinkovej strany a jej naviazania na cirkev a klérus a zároveň problémového politického programu autonomistov, ktorí evanjelikom aj z historických dôvodov, rovnako ako z dôvodov lojality voči nábožensky neutrálnemu Československu, nemohol vyhovovat'. Podobne ani vytvorenie Demokratickej strany nebolo prejavom boja evanjelikov proti komunistom (evanjelici boli aj v Komunistickej strane), ale vyjadrením snahy časti prvorepublikových elít a nekomunistických politických síl vytvorit po krachu ludáckej politiky vojnovej Slovenskej republiky politickú alternatívu voči silnejúcim komunistom.

Časti pracujúce s reáliami zo Slovenska sú v celej knihe bud' vel'mi nekonkrétne a nevyargumentované, alebo sú postavené na neznámych zdrojoch. Takto sa čitatel' môže dozvediet', že po nástupe komunistickej strany k moci bola v otázke náboženstva situácia na Slovensku odlišná. „Aj ked” aj tu došlo $k$ monsterprocesom, internácii biskupov a likvidácii rímskokatolíckych kláštorov (slovenským špecifikom bolo vynútené splynutie gréckokatolíckej cirkvi s pravoslávnou), komunistický režim musel byt' opatrnejší a niektoré proticirkevné zásahy zmierňovat." [s. 43] Nedozvieme sa $\mathrm{v}$ čom bol a musel byt' opatrnejší, ani v čom bol režim miernejší na Slovensku ako v českej časti štátu. Platila v oboch častiach odlišná legislatíva? Alebo boli odlišné kompetencie rôznych štátnych orgánov? To sa $z$ knihy nedozvieme, lebo od počiatku 50. rokov autor preskočil na obdobie „Pražskej jari“. Celkovo je zhodnotenie obdobia vlády komunistickej strany prezentované vel'mi schematicky a bez podrobnejších argumentov.

Dost́ nesystematicky pôsobí $\mathrm{v}$ tejto kapitole prechod od čias vlády komunistickej strany k ponovembrovému vývoju. Je to stručná a trocha nesystémová vsuvka. Konštatovat', že v období zmeny politického režimu v roku 1989 „triumfovali krestanské politické strany a politicky inštrumentalizovaný katolicizmus, ktorý sa stal jedným z vítazov nežnej revolúcie“ [s. 45] je prinajmenšom odvážne. Po prvé preto, lebo v tom čase okrem malej madarskej politickej strany existovala iba jedna otvorene krestáanská či katolícka politická strana - Krestáanskodemokratické hnutie, po druhé preto že táto strana napriek vel'kým mediálnym očakávaniam v prvých slobodných vol'bách v roku 1990 (teda pol roka po zmene režimu) dosiahla len asi $20 \%$ podporu. Bol to síce historicky najväčší úspech $\mathrm{KDH}$ vo vol'bách, no nestačil na to, aby mohli zostavovat́ vládu a aj v neskorších obdobiach, $\mathrm{s}$ jedinou výnimkou, boli vo vládach len koaličným partnerom silnejších zoskupení (ak boli vo vláde). Trocha zvláštne a skôr ako náhodne vložená pôsobí tabul'ka č. 2 [s. 45]. Je uvedená v časti týkajúcej sa obdobia asi do roku 1990, no obsahuje údaje len z celého nasledujúceho obdobia, teda od roku 1991 až do roku 2017. 


\section{Analýza inštitúcií}

Je zrejmé, že viac ako religiozite sa autor v knihe venuje inštitucionalizovaným podobám náboženstva - cirkvám a právnej regulácii náboženského života, teda úlohe štátu. Toto otvorene konštatuje aj v úvode tretej kapitoly Štát a cirkvi, v ktorej sa však už zaoberá obdobím po roku 1993, teda v čase existencie dvoch samostatných štátov. Názov tretej kapitoly je však zvolený trocha neštastne, ked'že naznačuje, akoby sa práve v nej kompletne riešili vztahy štátu a cirkví, no aj štvrtá kapitola o financovaní cirkví je súčastou týchto vztáahov.

Tretia kapitola sa podobne ako tá úvodná pokúša postaviť situáciu v Česku a na Slovensku do širšieho celoeurópskeho rámca (prekvapujúco s presahom popisov aj na model v USA), najmä pri vymedzovaní troch hlavných modelov vztahov štátu a náboženstva - od modelu štátnej cirkvi, cez zmiešaný model k odlukovému modelu. No definícia odlukového modelu, vnútorne rozporná, sa však zároveň prekrýva (zasahovaním štátu do náboženského pola) s definíciou zmiešaného modelu. Do tejto skupiny zarad'uje väčšinu krajín Európskej únie (až 19) vrátane Českej republiky (prinajmenšom do roku 2012), no aj Slovensko. Takto sa v knihe napriek predchádzajúcemu výpočtu množstva zásadných odlišností medzi Českom a Slovenskom objavujú obe krajiny ako príklady zmiešaného modelu vztáahov štátu a cirkví. Pre čitatel'a sa preto môže vynoritł otázka, prečo bola použitá typológia troch modelov, ak pre potreby analýzy situácie v Cesku a na Slovensku táto typológia neposkytuje žiadne interpretačné možnosti. Sú si oba systémy vztáahov tak podobné a aj autor chcel zdôraznit', že ich možno zaradit' do jedného druhu vztahov alebo chcel zdôraznit' ich rozdielnost́ v rámci zmiešaného typu, čomu sa však nevenoval (ak nerátame asi trojriadkový komentár)?

Rovnako neukotvene pôsobí použitie indexu náboženskej monopolizácie od autorov Chavesa a Canna, ktorý „má slúžit' $k$ vysvetleniu rozdielov v religiozite medzi jednotlivými krajinami". Jeho predpokladom je, "že monopolné postavenie vedie $k$ zníženiu náboženskej vitality, zatial čo konkurenčné demonopolizované prostredie ju bude naopak zvyšovat" [s. 49]. Napriek tomu, že autor sa tomuto indexu venuje a aj popisuje jeho dimenzie, nielenže ho v prípade Česka a Slovenska vôbec nevyhodnocuje, ale ani nereflektuje, či sú použitel'né a platné v našom geografickom priestore predpoklady, na ktorých index stojí. Už len laický pohlad na konštrukciu indexu a jeho definíciu naznačuje, že ak by bol platný, v Česku by mala byt’ vyššia a dynamickejšie rastúca religiozita oproti Slovensku, ktoré sa ovela silnejšie (a to aj podla skorších tvrdení autora) približuje modelu štátnej cirkvi alebo náboženského monopolu. No aj najjednoduchšie porovnávania ukazujú, že situácia je presne opačná. V tejto časti je znehodnotený akýkol'vek vysvetlujúci potenciál teórie racionálnej vol'by pri vysvetl'ovaní náboženskej zmeny, ktorú sa pokúsil ovel'a kompaktnejšie a systematickejšie využit' v knihe citovaný, no nijako nereflektovaný autor Pavol Minárik. Pri porovnávaní legislatívy regulujúcej náboženský život je už autor dôkladnejší a naznačuje nie-len odlišnosti prijímaných modelov v Česku a na Slovensku, ale aj reálne dôsledky na pluralizáciu, prípadne konzerváciu pôvodných náboženských polí. V kontexte vyššie uvedených pri- 
pomienok pôsobí návrat autora $\mathrm{v}$ nasledujúcom texte $\mathrm{k}$ indexu monopolizácie (neskôr označovanej nielen ako náboženská, ale aj ako cirkevná) v popise vývoja situácie v Česku nekoncepčne. Index už totiž nijako nespája so zmenami v religiozite, ako naznačuje pôvodný koncept založený na teórii racionálnej vol'by, ale rieši ho už len na úrovni fungovania inštitúcií.

Jadrom práce a jej najpodrobnejšie spracovanou častou je kapitola venujúca sa právnej regulácii náboženského života v Českej republike od roku 1993. Tu treba ocenit' prehl'adnú analýzu zmien v registrácii cirkví, kde upozorňuje na špecifiká nového českého cirkevného zákona z roku 2001, ktorý zaviedol nové pravidlá týkajúce sa registrácie, no zároveň vytvoril dve kategórie cirkví. Na rozdiel od viacerých rozšírených dezinterpretácií, že zákon zaviedol dvojstupňovú registráciu, autor upozorňuje, že zaviedol princíp takzvaných „špecifických práv“, ktoré síce boli automaticky priznané všetkým dovtedy registrovaným cirkvám, no nie všetkým v plnom rozsahu, čo prehl'adne popisuje v tabul'ke č. 3 [s. 54-55]. Žial', $\mathrm{v}$ knihe je vel'mi malý priestor venovaný dôvodom, prečo má väčšina cirkví iný zoznam priznaných „„špecifických práv“. Teda či šlo o odlišné požiadavky cirkví, alebo o odlišnú vôlu štátnych orgánov priznat' cirkvám rôzne práva . Je totiž zásadný rozdiel, či si niektoré práva cirkev neuplatňuje, lebo ich z rôznych dôvodov nepotrebuje a nechce, alebo či ich nemôže uplatňovat' $z$ dôvodu rozhodnutia štátnych orgánov.

Môže to pôsobit' ako l'penie na detailoch, ale pri analýze náboženského poĺa na Slovensku je nutné rozlišovat' nielen na úrovni rímskokatolícka cirkev (vrátane gréckokatolíckej) verzus ostatné, ako tomu je v prípade reflexie dohôd štátu s cirkvami po roku 2000. No v rámci registrovaných nekatolíckych cirkví je dôležité rozlišovat' medzi tými, ktoré majú dohody so štátom a poberajú finančné príspevky a tými registrovanými, ktoré tieto možnosti nevyužívajú. Viaceré z malých registrovaných cirkví totiž dobrovol'ne nevyužívajú finančné príspevky od štátu a dobrovolne nemajú zmluvu so štátom. No tie z nich, ktoré boli registrované až po roku 2000 sa na zmluve so štátom podielat' nemôžu, lebo by $\mathrm{s}$ takouto možnostou museli súhlasit' všetky ostatné zmluvné strany. Po prijatí nového zákona o financovaní cirkvi v roku 2019 sa tie cirkvi, ktoré v súčasnosti nepoberajú finančný príspevok nebudú môct’ oň v primeranej miere uchádzat' ani v budúcnosti. To sa týka aj akejkolvek novej cirkvi, ktorá by v budúcnosti na Slovensku bola zaregistrovaná.

\section{Financovanie cirkví}

Štvrtá kapitola patrí k analyticky silnejším, hoci v podstate obsahovo vo výraznej miere nadväzuje na tretiu kapitolu o regulácii náboženského života štátom. Pomerne podrobne vypočítava rôzne legislatívne normy týkajúce sa ekonomického zabezpečenia cirkví. Autor začína svoj výklad trocha nečakane, čo neznamená, že nelegitímne. Východiskom jeho uvažovania o cirkvách boli otázky spojené s reš- 
titúciami cirkevných majetkov a až následne sa dostal k samotnému priamemu financovaniu cirkví štátom, čo by sa podla názvu mohlo zdat' hlavnou témou tejto kapitoly. Je prekvapujúce, že pri popise prvých podôb reštitúcií časti cirkevného majetku (teda agenda týkajúca sa v podstate len rímskokatolíckej cirkvi), v období po revolúcii v roku 1989 až do rozpadu Československa v roku 1992, nie je vôbec spomenutá problematika týkajúca sa štátneho regulovania konfliktov pri sporoch o majetky na Slovensku medzi pravoslávnou a gréckokatolíckou cirkvou. Śtát vtedy aktívne urovnával spory o ich majetkové práva finančnými dotáciami (mimochodom konflikt, ktorý vznikol aj v súvislosti s počínajúcimi debatami o reštitúciách) a teda do nasledujúcich reštitúcií vstupovali tieto dve cirkvi v odlišnom kontexte a s (majetkovo) vylepšenou štartovacou dráhou.

Podobne dost́ nepodložene pôsobí výpočet rastu výdavkov SR na cirkvi v rokoch 2000-2018, ked autor konštatuje, že tento rast nezodpovedal rastu HDP 2000 až 2008 (prečo práve $v$ tomto krátkom období?). Naznačuje tým, akoby bolo alebo malo byt financovanie nejako spojené s rastom HDP. No financovanie cirkví na Slovensku a ani v Československu nebolo nikdy viazané na rast HDP, ale na priemerné platy, prípadne minimálnu mzdu či infláciu, podobne ako $\mathrm{v}$ iných sektoroch. Rast výdavkov na platy by preto teoreticky mohol byt porovnávaný $\mathrm{s}$ výdavkami na platy v iných sférach verejného života. No k tomu by musela byt' odčlenená čast̆ určená na platy duchovným od príspevkov na prevádzku cirkví. No v prípade menších cirkví môže tvorit' ovela väčšiu čast' príspevku, ako je tomu vo vel'kých ludových cirkvách s množstvom kňazov.

Nekonzistentne, pri pohlade na pôvodne prezentované myšlienky, že reštitúcie by mali byt' spojené so zmenou spôsobu financovania cirkví, pôsobia úvahy v daalších kapitolách knihy o reštitúciách v ČR. Túto čast' autor otvára tvrdením, že samostatné Slovensko rýchlo dotiahlo do konca pôvodné československé snahy o návrat „štandardného" ekonomického zabezpečenia cirkevnej prevádzky a stalo sa v tomto zmysle faktickým vzorom pre d'alšie postkomunistické krajiny strednej a východnej Európy [s. 74]. Autor týmto na jednej strane naznačuje, že neskôr prijatý model v ČR sa odklonil od pôvodných ideí a je neštandardný, na druhej strane však ničím nepodložil, v čom bol slovenský príklad inšpiráciou alebo vzorom pre iné krajiny a pre ktoré. Uvádzaný vzorový model, aký momentálne existuje na Slovensku (a aj po roku 2019) je jedinečný, prísne reštriktívny voči možným novým náboženským aktérom $\mathrm{k}$ získaniu takejto podpory a zásadne odlišný od pol'ského, madarského a aj iných modelov.

Dôležité je však pripomenút, že autor spomína aj daalšie súvislosti cirkevných reštitúcií. $K$ vecným zámerom reštitúcií cirkevných majetkov uviedol, že v ich prípade "nepôjde len o fyzické vrátenie majetku, ale tiež o náhradu d’alších krívd, ktoré boli cirkvám v období komunistickej vlády spôsobené. A to ako majetkových, tak nemajetkových, že nemohli svoj majetok využívat', ani sa oň adekvátne starat', čím došlo k jeho devastácii, tak nemajetkových v podobe obmedzovania náboženského života a postihovania cirkví a veriacich." [s. 77] Práve tento bod cirkevných reštitúcií nie je v práci dostatočne reflektovaný a je braný len ako samozrejmost. Neukazuje, ako sa táto 
argumentácia odkláňa od pôvodných všeobecných reštitučných zámerov z obdobia tesne po revolúcii v roku 1989 [Přibáň 2015]. Na jednej strane tým, že šlo o výnimku zo zásady, že reštitúcie sa budú uplatňovat' len na fyzické osoby, na strane druhej, že v prípade cirkevných reštitúcií sa neriešilo len samotné vrátenie majetku v stave, v akom bol (čo bol prípad reštitúcií fyzickými osobami), ale sa hladali aj formy odškodnenia za nemožnost' zhodnocovat' alebo za znehodnotenie reštituovaného majetku v období rokov 1948-1989. Toto naznačuje paradigmaticky odlišný prístup v zdôvodňovaní aj v obsahu rôznych druhov reštitúcií, kde reštitúcie cirkevného majetku fungovali vo vel'mi špecifickom a výrazne zvýhodňujúcom móde oproti iným subjektom, ktorých sa reštitúcie týkali. K tomu treba prirátat' ešte jedno špecifikum zákonov týkajúcich sa reštitúcií. $V$ prípade takzvaných reštitučných zákonov týkajúcich sa náboženského života sa prepojili dva princípy: krivdy a neprávosti z hladiska nového právneho rámca spáchané na jednotlivcoch z dôvodu ich náboženskej viery a zároveň potláčanie práv cirkví. Toto previazanie neprávosti voči jednotlivcom a kolektívnym náboženským entitám v predmete reštitučného práva vyradilo z oprávnených subjektov tých veriacich, ktorí neboli v čase štátneho socializmu príslušníkmi štátom uznávaných cirkví, ktoré boli vtedajším zákonodarstvom regulované a ktorých sa aj týkali tzv. náboženské trestné činy. Práve tieto trestné činy boli predmetom rehabilitácií a aj následných reštitúcií. No známe sú aj prípady potláčania náboženského života a aj trestných konaní voči príslušníkom nelegálnych náboženských skupín ako boli príslušníci Náboženského spoločenstva Svedkovia Jehovovi alebo tzv. Moonisti, teda členovi Cirkvi zjednotenia. $V$ prípade týchto štátom neuznaných cirkví však bývali dôvodom perzekúcií iné ako náboženské zákony. Takže reštitúcia, teda náprava krívd sa týkala len tých, ktorí boli legálnou súčastou vtedajšieho štátom uznávaného sveta a porušovali jeho vtedajšie chápanie a definovanie náboženstva.

Treba tiež pripomenút, že diskurz o nemajetkových ujmách na živote cirkví a veriacich a o potrebe ich kompenzovat' sa stal súčastou reštitučných zákonov výraznejšie v Českej republike. Na Slovensku bol tento naratív súčastou iného procesu. Viac ako súčast́ou zákonov a vyrátavania majetkového či finančného odškodnenia pri reštitúciách v roku 1993 (definitívne uzatvorenom v roku 2005) sa stal súčastou politického diskurzu legitimizujúceho pokračovanie v priamom financovaní cirkví a aj neskôr pri zmene zákona o financovaní cirkví a navyšovania rozpočtu pre cirkvi v roku 2019. Takto sa v oboch krajinách subjektmi vyjednávania o odškodnení, ale aj o daalších právnych normách týkajúcich sa náboženského života stali len tie cirkvi, ktoré pôsobili v rámci krajiny pred rokom 1990 a do nového politického režimu vstúpili so zákonnou možnostou byt’ financované zo strany štátu. Tým, že autor zdôraznil zavedenie finančnej odluky cirkví od štátu zákonom z roku 2012 v Česku, potlačil do úzadia legislatívne mechanizmy reprodukcie jadra náboženského pola, ktoré bolo takmer rovnaké v Česku i na Slovensku v podstate ešte vyše dvadsat' rokov po zmene režimu.

Autor v časti o financovaní cirkví v Česku naráža na jeden bod, ktorý bol vel'mi často využívaný aj pri legitimizácii katolíckej cirkvi ako najsolidárnejšieho 
aktéra na náboženskej scéne na Slovensku. Uvádza nerovnaké výšky finančných prostriedkov pre rôzne cirkvi, kde výška podpory zdanlivo vychádzala $\mathrm{v}$ prospech menších a v neprospech väčších cirkví. Autor [s. 78-79], rovnako ako aj mnohí cirkevní predstavitelia tieto konštatovania o spravodlivosti, prípadne solidarite väčších s menšími odvodzuje z výpočtu sumy, akú dostávajú cirkvi z rozpočtu štátu a počtu veriacich, teda podla údajov z cenzov, kol'kí ludia sa prihlásili k cirkvi. Obišiel pritom fakt, že klúčovou zložkou príspevkov od štátu boli, a to v oboch krajinách, príspevky na platy duchovných a len zvyšok, kde mohlo dôjst' k uvádzaným nerovnostiam, bol pridelovaný ústrediam cirkví. Tento princíp výpočtu podpory pre cirkvi najmä podla počtu duchovných a nie podla počtu veriacich (doplnený o paušálnu sumu určenú na prevádzku ústredí cirkví) platil v Československu od roku 1949 a rovnako platný bol aj v nástupníckych štátoch - v Česku do roku 2012, na Slovensku do roku 2019. Inými slovami, nie počet prihlásených v sčítaní (v rokoch 1960-1990 také údaje ani neexistovali), ale najmä počet duchovných bol rozhodujúcim kritériom pre výšku finančnej podpory od štátu. Druhým vysvetlením tejto zdanlivej nespravodlivosti je aj fakt, že náklady na zabezpečenie náboženského života $\mathrm{v}$ menších alebo rozptýlených komunitách bývajú vyššie ako v prípade vel'kých organizácií. Teda ak už štát mal záväzky voči cirkvám, že bude primerane zabezpečovat' ich základné potreby pre fungovanie, ktoré si stanovil ešte v roku 1949, počas platnosti zákona toto musel zohl'adňovat'. Vzhladom na charakter a obsah zákona o hmotnom zabezpečení cirkví a náboženských spoločností tieto zdanlivé nespravodlivosti a nejasnosti už tak nepôsobia.

Zaujímavou, hoci metodologicky nejasnou častóou práce je priestor, kde sa autor zaoberá spoločenskými dôsledkami financovania cirkví. Aj tu totiž naznačuje slovenský model (celkovo výrazne menej detailne popísaný) ako istý druh normality, na rozdiel od českého, čo podporuje tvrdeniami, že na Slovensku proces reštitúcie cirkevných majetkov a štátnych príspevkov na prevádzku cirkví "nevyvolal žiadne vel'ké reakcie a dlhodobejšie neviedol k žiadnej výraznejšej kritike, $\checkmark$ Českej republike šlo po celý čas o mediálne a politicky vysoko citlivú otázku. Komplikovanú naviac tým, že prakticky všetky verejné diskusie zdôrazňovali iba reštitučný aspekt, [...] bez toho, aby zohladňovali, že štát súčasne náboženské spoločnosti prestáva finančne podporovat." " [s. 83] Chýba tu opät' komparatívny pohl'ad, ked’že na Slovensku síce reštitúcie prebehli skôr, no bez toho, aby štát ukončil ich financovanie. No na druhej strane nie je tiež jasné, na základe akej analýzy dospel autor k porovnaniu intenzity reakcií. V prípade českého prípadu to pôsobí ako tvrdenie opierajúce sa o analýzu médií. Ak by to isté platilo aj o Slovensku, bolo by to možné spochybniť, pretože práve téma cirkevných reštitúcií bola mediálne v rôznych vlnách silne prítomná na Slovensku až do ukončenia procesu v roku 2005 a vo vel'mi kritickom duchu diskusia pokračovala aj neskôr, a to aj v prípade zmeny financovania cirkví v roku 2019. Otázne však môže byt', ktoré médiá a akú populáciu zasiahli svojimi kritickými komentármi, no šlo o tému prítomnú počas najmenej dvoch dekád transformácie vztáahov štátu a cirkví. Ak však autor pod chýbajúcimi reakciami na Slovensku mal na mysli politickú debatu a spory pri presadzovaní zákonov, $\mathrm{v}$ tom prípade by to ale tak musel napísat. 


\section{Čo s teóriou a metodológiou?}

Piata kapitola knihy sa podla názvu zameriava na cirkvi ako organizácie. Zaujímavostou tejto kapitoly je, že sa v nej autor venuje nielen reorganizácii štruktúr katolíckej cirkvi v Česku (tam aj pomerne podrobne) a na Slovensku (asi troma vetami), ale aj rôznym škandálom pri formovaní teologického vzdelávania v nových spoločenských podmienkach v už samostatnej Českej republike. Sústredenie sa na škandály zredukovalo informácie o Slovensku na problém odvolania arcibiskupa Roberta Bezáka v roku 2012. V prípade viacerých týchto častí je úplne nejasná metodológia, ako autor došiel k svojim záverom - podobá sa to skôr na publicistiku alebo na vol'né prerozprávanie myšlienok neznámych informátorov. Podobne nejasnú metodológiu a zdroj informácií má aj čast́ o neregistrovaných náboženských skupinách, kde opät popisy situácie na Slovensku sú ovela stručnejšie a bez akýchkolvek odkazov na zdroje. Aj tu je popis fungovania malých neregistrovaných skupín odbitý jedným všeobecným odstavcom a formuláciami, aké v prípade Česka nie sú využívané. Na Slovensku sú malé skupiny v podstate exotizované a banalizované a to napriek tomu, že ich údajný počet (10 000-20 000 odhadovaných členov) je v podmienkach Slovenska pomerne výrazná množina, hoci rozptýlená do rôznych skupín. Však už len v prípade Budhizmu diamantovej cesty, o ktorom sa autor nezmieňuje, ide o niekol'kotisíc vyznavačov a o šestnást' centier vybudovaných po celom území Slovenska. Tým sa toto spoločenstvo zaraduje k najväčším neregistrovaným skupinám, početne väčším ako je väčšina $\mathrm{z}$ registrovaných cirkví [Centrá...]. Systematické obchádzanie podrobnejších analýz o situácii na Slovensku vedie autora k skratkám, ktoré apriórne vysvetlujú situáciu na Slovensku, ako spôsobenú "konzervativizmom vel'kej časti populácie“ [s. 104] (čo to vlastne je?) a silným postavením etablovaných cirkví. Tak ako na mnohých iných miestach, aj v tejto kapitole mechanicky stotožňuje oficiálnu politiku, výrazne reštriktívnu voči všetkým netradičným formám náboženského života, s populáciou krajiny, o ktorej konzervatívnosti nepodáva žiadne údaje a v podstate neberie do úvahy, že až štvrtina populácie nemá vzt́ah k tradičnej religiozite a ani politickú či inú formu zastúpenia v spoločnosti.

Táto čast' však jasnejšie odkrýva teoretické východiská práce, ktoré síce nie systematicky, ale najčastejšie zodpovedajú teórii racionálnej vol'by. V knihe je prítomný nielen teoretický základ tohto prístupu, ale aj jeho normatívna dimenzia posudzujúca normálnost', prirodzenost' či dokonca zdravost' fungovania cirkví v spoločnosti. Spomína "účinne fungujúci náboženský trh" (čo predpokladá, že inde je trh neúčinný alebo nie je) a ,zdravú konkurenciu medzi rôznymi aktérmi" (čo zasa predpokladá možnost́ konkurencie nezdravej alebo konkurencie neexistujúcej). Toto je ale celé zakončené skôr štrukúrnofunkcionalistickým a normatívnym konštatovaním, že české a slovenské cirkvi ustrnuli „, postavení organizačných molochov s t'ažkost'ami reagujúcimi na meniace sa spoločenské potreby“" [s. 105]. Do analýzy činnosti cirkví vnáša v podstate ich vlastné vnútorné dilemy, či majú byt゙ skôr zdrojom istoty a stability $\mathrm{v}$ meniacom sa svete, alebo sa prispôsobovat' zmene a íst's duchom doby. 
Do časti o náboženstve vo verejnej sfére je zaradená aj časť o cirkvách ako aktéroch v oblasti formálneho vzdelávania. Táto časț je už vyváženejšia z hladiska rozsahu aj obsahu venovaného obom krajinám, no aj tu sa autor nevyhol viacerým nepresnostiam. Napríklad legislatíva regulujúca cirkevné školstvo sa týka aj školstva súkromného. Obe formy boli naraz a za rovnakých podmienok zrovnoprávnené s verejným školstvom s tým, že systém financovania je (pri povinnej školskej dochádzke) odvodený od zásady, že štát prispieva finančne na študenta, a to bez ohl'adu na zriad'ovatel'a. Umožnenie súkromným subjektom zakladat́ školy nijako nesúvisí s možnostou ich odškodnenia za predchádzajúce obdobia, lebo tam neexistuje žiadna právna kontinuita právnych subjektov poskytujúcich vzdelávanie.

Podobne aj dalšia podkapitola o cirkevných sociálnych službách je najmä popisným výpočtom rôznych cirkvami zriad’ovaných organizácií, kde sa v rámci sociálnych služieb objavuje aj angažovanost ${ }^{\mathrm{v}}$ zriad'ovaní nemocníc, so špecifickým dôrazom na duchovnú službu v nemocniciach. Autor sem prekvapujúco zaraduje aj duchovnú službu v profesionálnych ozbrojených zložkách ako je armáda, polícia alebo duchovnú službu vo väzniciach. Celú kapitolu uzatvára zmienkou o úlohách cirkví v pohrebníctve, čo v kontexte kapitoly vyvoláva otázku, ako vlastne definuje sociálne služby. Pôsobí to tak, akoby každá služby cirkvi veriacim, prípadne aj neveriacim bola apriórne sociálnou službou. Obzvlášt mätúci je aj názov dảšej časti Sociálna dimenzia cirkeoných sociálnych služieb, akoby dovtedy uvádzané služby neboli sociálne alebo boli bez sociálnej dimenzie. Ani obsahovo nie je jasné, prečo museli byt́ v práci zaradené dve kratučké samostatné časti dotýkajúce sa toho istého predmetu.

Siedma kapitola nazvaná Spoločnost' v cirkvách a o cirkvách je v podstate spracovaním dvoch základných druhov kvantitatívnych údajov o náboženskom živote v oboch krajinách - údajov zo sčítaní obyvatelov a výsledkov medzinárodných výskumných programov zameraných na výskum náboženstva. Paradoxne až $\mathrm{v}$ úvode tejto kapitoly je naznačené, aké metodologické postupy boli zvolené v predchádzajúcich častiach knihy. Informácie o tom, že bolo použité „vonkajšie pozorovanie“, rozhovory s aktérmi, analýzy dokumentov a podobných zdrojov [s. 129] sú síce dôležité, no nijako neumožňujú zistit', ktoré závery boli vytvorené, z akých dát a akou metódou zozbieraných dát. Práve táto nepriznanost' metodológie pri budovaní argumentov je tou najslabšou stránkou predchádzajúcich častí. Napriek tomu, že táto čast' už je postavená na presných dátach, porovnávanie presných údajov o počtoch prihlásených $\mathrm{k}$ jednotlivým cirkvám a náboženstvám v oboch krajinách pôsobí t́ažkopádne. Problém, ako netriedené porovnávania vôbec interpretovat' zosilňuje aj fakt, že autor nenaznačil problematickost' porovnávania výsledkov sčítaní v Česku a na Slovensku a v každej krajine aj medzi jednotlivými sčítaniami. V podstate sa porovnávajú dáta, ktoré merajú niečo čiastočne odlišné. A už vôbec sa nedá hovoriť o tom, že by sa v sčítaniach merala religiozita, ako je to uvedené pod tabul'kou č. 6. Ide o zist́ovanie len jednej a aj to skôr formálnejšej stránky religiozity. V prípade Slovenska sa meralo len subjektívne 
prihlásenie sa k niektorej z registrovaných cirkví, alebo bola možnost' uviest' iné, či bez vyznania. Metodika bola postavená na jedinej otázke a v rokoch 2001 a 2011 s uvedením zoznamu možností [Tížik 2014]. Na rozdiel od toho v Česku sa v roku 2011 merala sebadefinícia obyvatela ako veriaceho alebo neveriaceho a až v druhom kroku sa tí, čo sa deklarovali za veriacich rozhodovali, ku ktorej cirkvi sa prihlásia alebo či budú deklarovat́ vieru bez prináležitosti k cirkvi. V Česku takto vznikli zo sčítania aj všeobecné kategórie neviažúce sa ku konkrétnym cirkvám, ako napríklad „katolícka viera“, „,krestáanstvo“, protestantská/evanjelická viera“, "ateizmus“, čo nemalo v sčítaní na Slovensku obdobu. Okrem toho, chýba dovysvetlenie, že vysoký podiel neodpovedajúcich v Česku bol spôsobený aj tým, že $\mathrm{v}$ českom sčítaní šlo o dobrovolnú otázku, zatial čo na Slovensku to bola povinná položka. Inými slovami, v oboch krajinách sa nielen merali odlišné javy, ale aj odlišnou metódou.

Poslednou častou je sumarizácia záverov knihy a načrtnutie možných dalších perspektív vývoja religiozity. No niektoré závery sú prekvapujúco v protiklade s tézami v samotnej knihe. Napríklad, ak o Slovensku o pár strán skôr autor hovorí ako o krajine tradične religióznej a tradicionalistickej a v prípade Česka ukazuje úpadok religiozity, záver, že v Česku a na Slovensku možno hovorit’ o "návrate náboženstva“ [s. 151] pôsobí prinajmenšom rozporuplne. Dost' nesystémovým prvkom $\mathrm{v}$ knihe je záverečná príloha, ktorá obsahuje ukážku z rozhovorov s viac ako dvadsiatimi príslušníkmi (v mnohých prípadoch pravdepodobne predstavitel'mi) cirkví v Česku a na Slovensku. Podobne ako aj na mnohých iných miestach $\mathrm{v}$ knihe chýba ich elementárna analýza a presné roztriedenie podla nejakých kritérií, ako boli respondenti oslovovaní. Úplná dekontextualizácia a vynechanie systematickej analýzy, kódovania a triedenia výpovedí posúvajú túto prílohu do úlohy nadbytočnej časti knihy.

Ako bolo uvedené na začiatku, kniha je tematicky a aj šírkou záberu v českom a slovenskom prostredí priekopnícka. No trpí nedostatkami, na ktoré sama v úvode poukazuje, ked hodnotí situáciu v skúmaní náboženstva na Slovensku a v Česku. No okrem toho do popredia vystupujú dva zásadné problémy, ktoré však nie sú pri takýchto obsiahlych publikáciách ojedinelé - problém s prácou $\mathrm{s}$ dátami a teoretické východiská. Práca s dátami je $\mathrm{v}$ tomto prípade nesystematická a obzvlášt pri komparatívnej práci sa nedajú bez porovnatel'ných dát a bez reflexie ich metodológie urobit žiadne zmysluplné závery. Ako konštatoval Váně popisujúci situáciu v Česku (a platí to aj o Slovensku), už nie je problém, že by nebol dostatok dát o náboženstve a religiozite, ale problémom je konceptualizácia týchto dát a ich aplikácia (obzvláštt kvalitatívnych) [Váně 2012: 376]. A to je aj druhým, ovela závažnejším problémom knihy. Závery nielenže nie sú ukotvené vo výsledkoch citovaných dát, chýba im najmä nejaké teoretické ukotvenie. Hoci na mnohých jej miestach preniká teória racionálnej vol'by, nie je to práca postavená systematicky na tomto prístupe a tým sa odlišuje napríklad od explicitnejšie takto vymedzenej knihe Pavla Minárika [Minárik 2018]. Množstvo dôležitých analýz, postrehov a príkladov tak zostalo neusporiadaných do kompaktného 
celku a kniha ako celok naplnila závery analýzy Romana Vida o skúmaní náboženstva v Česku po roku 1990. Deficit sociológie náboženstva v Česku sa vztahuje k neschopnosti prekročit rovinu popisu a historického ukotvenia a poskytnút presvedčivé sociologické vysvetlenie zmien $\mathrm{v}$ českej religiozite a vidiet' absenciu "koherentného teoretického rámca“, prax „ad hoc" využívania sociologických teórií a konceptov sprevádzaná tendenciou k (teoreticky explicitne nezdôvodnenej) "historizácii sociologického výskumu“ [Vido 2019: 440]. Obzvlášt” sa to ukazuje pri tak unikátnom výskume, akým je situácia v bývalom Československu, kde sa $\mathrm{z}$ jedného, sedemdesiat rokov budovaného systému postupne vytvorili systémy dva a kde práve teoretické ukotvenie môže pomôct' nasmerovat' skúmanie pri pokuse vysvetlit existujúce rozdiely alebo hoci aj pretrvávajúce podobnosti.

Miroslav Tižik

Sociologický ústav SAV a Katedra sociálnej práce Pedagogickej fakulty Univerzity Komenského v Bratislave https://doi.org/10.13060/csr.2021.009

\section{Literatúra}

Bourdieu, P. 1998. Teorie jednání. Praha: Karolinum.

Bunčák, J. 2001. „Religiozita na Slovensku: stredoeurópsky rámec.“ Sociológia 33 (1): 47-69.

Bubík, T. 2015. „The Czech Journey to the Academic Study of Religions: From the Critique of Religion to its Study." Pp. 1-54 in T. Bubík, H. Hoffman (eds.). Studying Religions with the Iron Curtain Closed and Opened: The Academic Study of Religio in Eastern Europe. Leiden and Boston: Brill, https://doi.org/10.1163/9789004292789_002.

"Centrá buddhizmu diamantovej cesty na Slovensku." Buddhizmu diamantovej cesty [online]. Spoločnosť buddhizmu Diamantovej cesty [navštívené 20. 1. 2021]. Dostupné na: http://www.buddhizmus.sk/?go=centra.

Klobucký, R. 2006. Hlasistické hnutie: národ a sociológia. Začiatky sociologického myslenia na Slovensku. Bratislava: Sociologický ústav SAV.

Kusá, Z., M. Tížik (eds.). 2009. Výskum európskych hodnôt 1991-1999-2008 slovenská a česká spoločnost' : pramenno-analytická publikácia [online]. Bratislava: Sociologický ústav SAV. Dostupné na: http://www.sociologia.sav.sk/cms/uploaded/1776_attach_EVS_ CS_2008.pdf.

Lajčiak, J. 1994. Slovensko a kultúra. Bratislava: Q111.

Majo, J. 2011. "Shrinking Minority. Slovak Lutheranism Fighting With Secularism.“ Journal for the Study of Religions and Ideologies 30 (10): 39-55.

Majo, J. 2013. „Vybrané charakteristiky transformácie religiozity na Slovensku v rokoch 1950-2001 vo vztahu k sekularizácii." Geografický časopis 65 (3): 217-234.

Majo, J., B. Šprocha. 2016. Storočie populačného vývoja Slovenska II - populačné štruktúry. Bratislava: Infostat, CSPV SAV, Univerzita Komenského v Bratislave. 
Matlovič, R. 2001. Geografia relígií. Náčrt problematiky. Prešov: FHPV Prešovskej univerzity $\mathrm{v}$ Prešove.

Minárik, P. 2018. Ekonomie náboženství a náboženství v postkomunistické Evropě. Brno: Masarykova univerzita, Univerzita J. E. Purkyně, https://doi.org/10.5817/CZ.MUNI.M210-9125-2018.

Přibáň, J. 2015. „Politika verejného poznania a právnej spravodlivosti pri vyrovnávaní sa s minulostou: postkomunistické skúsenosti a nedávne ponaučenia z Českej republiky." Pp. 30-59 in A. Kvasničková a kol. Pamät' v transdisciplinárnej perspektíve. Bratisava: Univerzita Komenského v Bratislave.

Tížik, M. 2012. „Religion and National Identity in an Enlarging Europe.“ Pp. 101-123 in F. Höllinger, M. Hadler (eds.). Crossing Borders, Shifting Boundaries: National and Transnational Identities in Europe and Beyond. Frankfurt-on-Main: Campus Verlag $\mathrm{GmbH}$.

Tížik, M. 2014. „Kvalita merania náboženskej prináležitosti na Slovensku.“ Slovenská štatistika a demografia 24 (3): 49-70.

Václavík, D. 2015. „Searching and Finding: A History of the Slovak Study of Religion." Pp. 55-86 in T. Bubík, H. Hoffman (eds.). Studying Religions with the Iron Curtain Closed and Opened: The Academic Study of Religio in Eastern Europe. Leiden and Boston: Brill, https://doi.org/10.1163/9789004292789_003.

Váně, J. 2012. „Výzkumy věnující se podobám religiozity v České republice po roku 1989.“ Pp. 355-398 in J. Krejčí, Y. Leontiyeva (eds.). Cesty k datům. Zdroje a management socialněvědních dat v České republice. Praha: Sociologické nakladatelství (SLON).

Váně, J., M. Štípková. 2013. „The National Religious Environment and the Orthodoxy of Christian Beliefs: A Comparison of Austria, the Czech Republic and Slovakia." Sociologický časopis / Czech Sociological Review 49 (3): 403-425, https://doi.org/10.13060/00380288.2013.49.3.03.

Vido, R. 2019. „Jak (ne)vysvětlit českou bezbožnost? Analytická sociologie jako inspirace pro sociologii náboženství.“ Sociológia 51 (4): 420-443, https://doi.org/10.31577/sociologia.2019.51.4.19. 